\title{
PEMANFAATAN PEMROGRAMAN MULTIUSER UNTUK MANAJEMEN ANGGARAN PENDAPATAN DAN BELANJA DESA (APBDES)
}

\author{
Febryantahanuji ${ }^{1}$, Wiyanto ${ }^{2}$ \\ 1,Manajemen Informatika, Sekolah Tinggi Elektronika dan Komputer \\ Jln. Majapahit No. 605 Semarang \\ 1 febryan@stekom.ac.id, ${ }^{2}$ wiyanto@gmail.com
}

\begin{abstract}
The Village Fund Budget is a revenue-sharing fund between the District and Village Governments for the welfare of the community. The budget obtained is managed by the village government for development and community welfare. Problems that exist in the preparation of the budget must use a ledger and then make use of Microsoft Excel where it will increase the length of work time because you have to understand excel logic. The absence of databases and security systems that are not yet available is a consideration for the need for a system to conduct management of village expenditure budget management that will make time faster and more accurate in budgeting. Utilization of Visual Basic 6.0 with MySql database and R \& D research method developed by Borg and Gall (1983) through the following stages: Research and information collecting, Planning, Develop prelminary form of product, Prelminary field testing, Main product revision, Main field testing. With the use of a system that has integrated the budget management database will be faster and with the existence of a security system which will prevent individuals who are not authorized to manipulate data.
\end{abstract}

Keywords : management informatics, management, village funds, multiuser

\begin{abstract}
Abstrak
Anggaran Dana Desa merupakan dana bagi hasil antara Pemerintah Kabupaten dan Desa untuk kesejahteraan masyarakat. Anggaran yang didapatkan dikelola oleh pemerintah desa untuk pembangunan dan keejahteraan masyarakat. Permasalahan yang ada dalam penyusunan anggaran harus menggunakan buku besar lalu membuat menggunakan Microsoft Excel dimana akan menambah panjang waktu pengerjaan karena harus memahami logika excel. Belum adanya database serta sistem keamanan yang belum tersedia menjadi pertimbangan dibutuhkannya sebuah sistem untuk melakukan sebah manajemen pengelolaan anggaran pendapatan belanja desa yang akan membuat waktu lebih cepat dan akurat dalam penyusunan anggaran. Pemanfaatan Visual Basic 6.0 dengan database MySql serta metode penelitian R\&D yang dikembangkan oleh Borg and Gall (1983) yang melalui tahap sebagai berikut: Research and information collecting, Planning, Develop prelminary form of product, Prelminary field testing, Main product revision, Main field testing. Dengan pemanfaatan sistem yang sudah terintegrasi database pengelolan anggaran akan lebih cepat dan dengan adanya sistem keamanan dimana akan mencegah oknum yang tidak berwenang untuk memanipulasi data.
\end{abstract}

Kata kunci : manajemen informatika, manajemen, dana desa, multiuser

\section{Pendahuluan}

Pentingnya sebuah instansi dalam melakukan manajemen terutama untuk pengelolaan anggaran dana sangatlah diperhatikan. Pada era saat ini penggunaan tekonologi informasi merupakan salah satu hal penting pada sebuah instansi, dikarenakan dapat meningkatkan performa instansi tersebut. Saat ini hampir setiap instansi dituntut untuk menggunakan teknologi dalam setiap kegiatannya, tanpa kecuali instansi swasta 
maupun pemerintah. Pada sebuah instansi pemerintah yaitu kelurahan Getas, dimana dalam pengelolaan dan manajemen anggaran dana desa masih menggunakan cara manual, mencatat semua anggaran pada buku besar lalu memindahkannya ke dalam Microsoft Excel (ms. Excel), dimana software tersebut belum terintegrasi ke dalam database sehingga data tidak bisa tersusun dengan rapi, apabila kepala desa ingin melihat laporan ms. Excel tidak dapat menampilkan secara periodik serta rawan manipulasi data dikarenakan tidak adanya hak akses untuk user. Database atau media penyimpanan ini akan memudahkan user untuk mencarinya apabila data-data didalamnya dibutuhkan (Agusli, 2017).

Dilihat dari permsalahan yang ada di atas, penulis memberikan solusi untuk agar manajemen anggaran dana desa dilakukan menggunakan komputerisasi yang sudah terintegrasi database serta dilengkapi hak akses user untuk meminimalisir oknum yang tidak bertanggung jawab ketika ingin memanipulasi data atau laporan. Ditegaskan pula oleh penelitian sebelumnya bahwa Dengan adanya Sistem Informasi Pengolahan Data ini dapat mempermudah dalam mencari data-data yang sudah ada tanpa mencari pada lemari berkasberkas atau arsip lagi, serta untuk mempercepat dalam proses pencarian data pada lemari berkas sesuai dengan petunjuk dari database (Juaini, 2018).

\section{Tinjuan Pustaka}

\section{A. Kajian Penelitian Relevan}

Penggunaan sistem komputerisasi untuk mengelola dana desa sebelumnya juga sudah pernah digunakan pada penelitian (Muhammad Ismail, 2016) dalam jurnal ilmiah yang berjudul sistem akuntansi pengelolaan dana desa, memberikan kesimpulan berdasarkan hasil penelitian diketahui bahwa aparat desa belum memiliki kesiapan dan belum memahami dalam pengelolaan dana desa. Penggunaan program sistem informasi akuntansi pengelolaan dana desa yang terkomputerisasi dapat mengatasi masalah terkait pengelolaan dana desa. Sistem komputerisasi akan memberikan kemudahan aparat desa dalam penyusunan dana desa mulai dari perencanaan, pencatatan secara akuntansi dan membuat laporan keuangan semesteran dan tahunan. Penggunaan sistem komputerisasi juga akan menghemat waktu aparat desa sehingga dapat lebih maksimal dalam memberikan pelayanan kepada masyarakat.
(Davis Budi Purnama, 2015) dalam jurnal ilmiah yang berjudul audit internal sistem informasi akuntansi pengelolaan alokasi dana desa (ADD) untuk menilai akuntabilitas kinerja desa (di desa batokan kecamatan kasiman kabupaten bojonegoro). Tidak adanya sistem informasi akuntansi pengelolaan dana desa mengakibatkan informasi yang jelas dalam pengelolaan alokasi dana desa. Perangkat desa yang kurang memahami alokasi dana desa yang dibuat dalam Anggaran Pendapatan dan Belanja Desa (APBDes). Tidak adanya penyampaian pertanggung jawaban kepada masyarakat karena pelaporannya hanya sebatas kepada Badan Permusyawaratan Desa Batokan yang kemudian infomasi tersebut disampaikan kepada mayarakat. Dari penjelasan di atas dapat diketahui bahwa dibutuhkan sistem informasi akuntansi yang dapat memudahkan di dalam prosedur serta tugas dan wewenang pemerintah desa dalam pengelolaan alokasi dana desa. Dengan adanya sistem informasi akuntansi perencanaan dan realisasi pengelolaan anggaran desa dapat sesuai yang diharapkan serta pembuatan laporannya dapat tepat waktu.

\section{B. Multiuser}

Multiuser merupakan sebuah program yang bisa digunakan secara bersama-sama, dari mesin yang sama dan diterminal yang sama atau berbeda (Parwati, 2014).

\section{Metodologi Penelitian}

Dalam penelitian yang dilakukan bertujuan untuk membuat sebuah aplikasi untuk pengelolaan anggaran dan pendapatan belanja desa berbasis multiuser. Penulis melakukan pengembangan dengan metode R\&D (Research and Development) menurut (Borg, 1983). menyatakan bahwa prosedur penelitian pengembangan pada dasarnya terdiri dari 2 tujuan utama, yaitu mengembangkan produk dan menguji keefektifan produk dalam mencapai tujuan. Terdapat 10 langkah yang terdapat dalam metode R\&D, tetapi penulis hanya menggunakan 6 langkah, yaitu Research and information collecting, Planning, Develop prelminary form of product, Prelminary field testing, Main product revision, Main field testing. Berikut adalah tahapan metode R\&D yang akan diterapkan oleh penulis: 


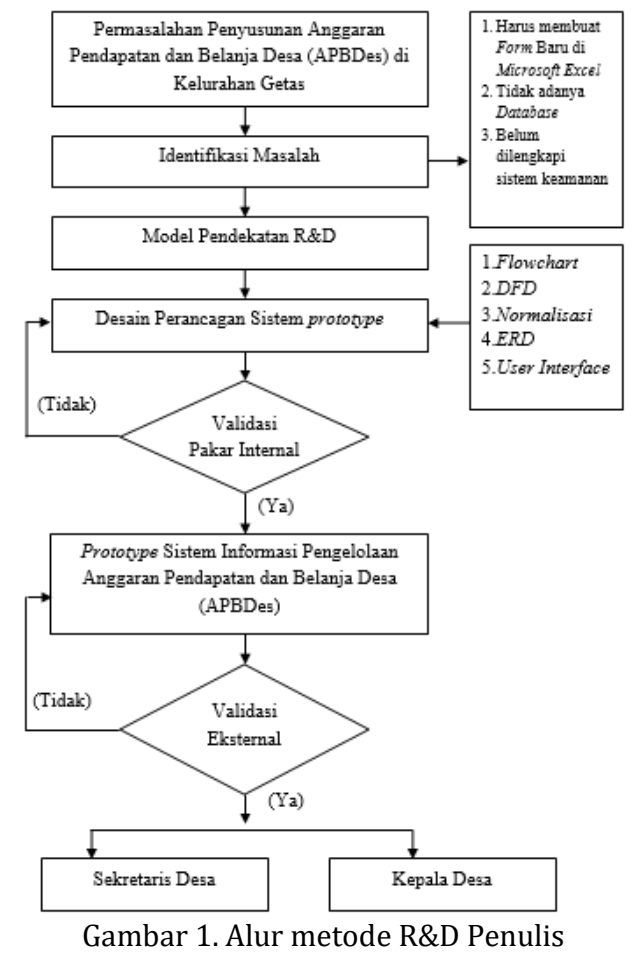

\section{Hasil dan Pembahasan}

Sistem yang dikembangkan menghasilkan prototype sistem informasi pengelolaan anggaran pendapatan dan belanja desa (APBDes) di kelurahan getas berbasis multiuser. Berikut adalah hasil sistem yang telah dikembangkan oleh penulis:

\section{A. Form Login}

Form Login digunakan untuk pembagian hak akses antara Sekretaris Desa dan Kepala Desa. Sekretaris Desa memiliki kewenagan untuk input data dan melakukan pengelolaan anggaran sedangkan Kepala Desa memiliki kewenangan untuk memeriksa laporan-laporan yang dikelola oleh Sekretaris Desa.

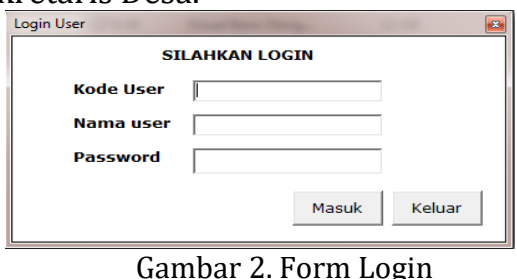

\section{B. Form Menu Utama Sekretaris Desa}

Untuk memilih menu yang dibutuhkan oleh Sekretaris Desa dalam input data anggaran pendapatan dan belanja desa (APBDes).

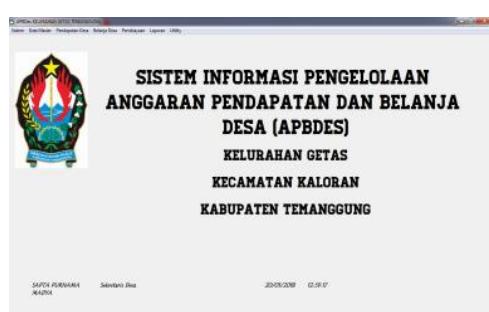

Gambar 3. Form Menu Utama Sekretaris Desa

\section{Form Master Rekening}

Form master rekening digunakan untuk membuat kode rekening.

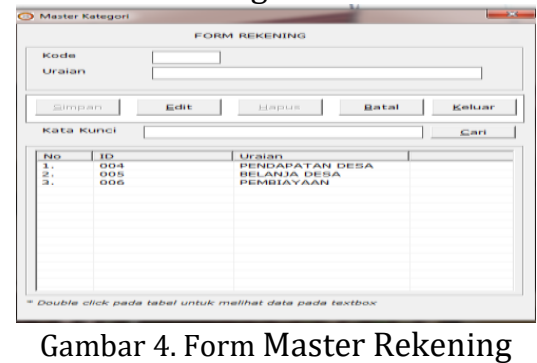

\section{Form Master Sub Rekening}

Untuk membuat sub kode rekening.

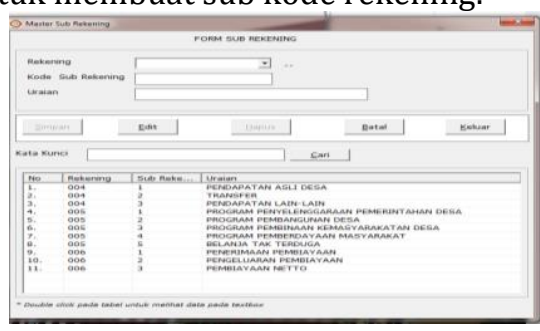

Gambar 5. Form Sub Master Rekening

\section{E. Form Pendapatan Desa}

Untuk input data pendapatan desa.

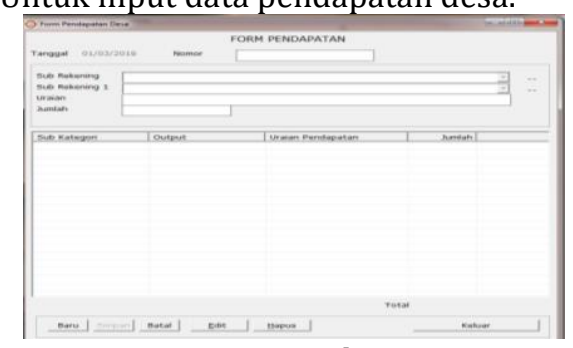

Gambar 6. Form Pendapatan Desa

\section{F. Form Belanja Desa}

Untuk input data belanja desa

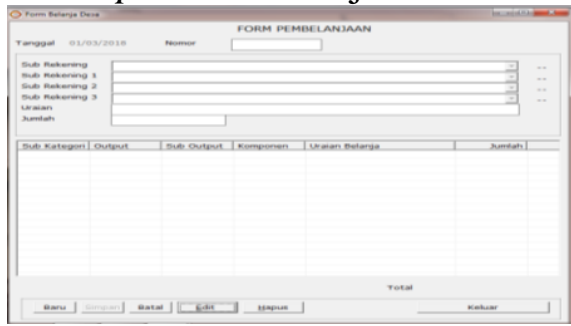

Gambar 7. Tampilan Form Belanja Desa 


\section{G. Form Pembiayaan}

Untuk input data pembiayaan.

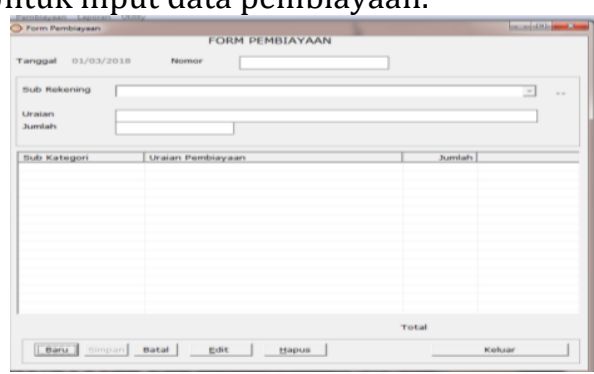

Gambar 8. Tampilan Form Pembiayaan

\section{H. Form Laporan Pendapatan}

Untuk menampilkan laporan pendapatan.

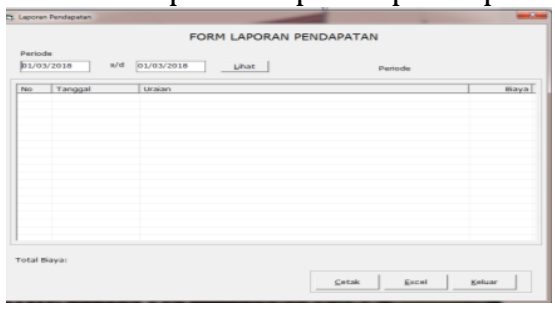

Gambar 9. Tampilan Form Laporan Pendapatan

\section{Form Laporan Ledger}

Untuk menampilkan semua laporan.

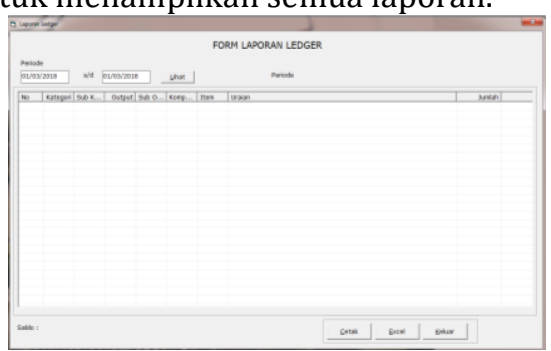

Gambar 10. Tampilan Form Laporan Ledger

J. Form Laporan Saldo

Untuk menampilkan laporan saldo.

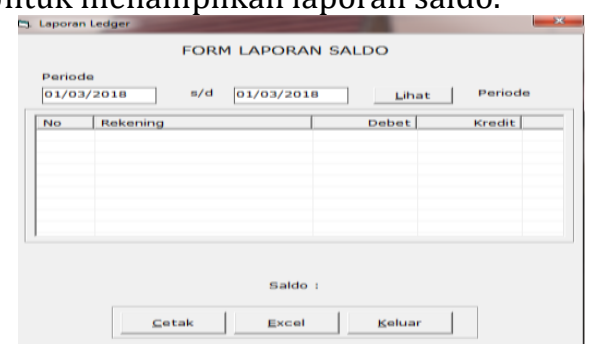

Gambar 11. Tampilan Form Laporan Saldo

\section{K. Form Pengolah Data Akses}

Digunakan untuk mengatur hak akses pengguna.

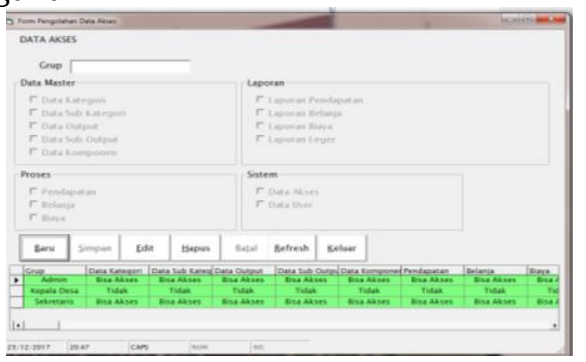

Gambar 12. Tampilan Form Pengolah Data Akses

\section{Form Master Data}

Digunakan untuk melakukan input data pemakai (user).

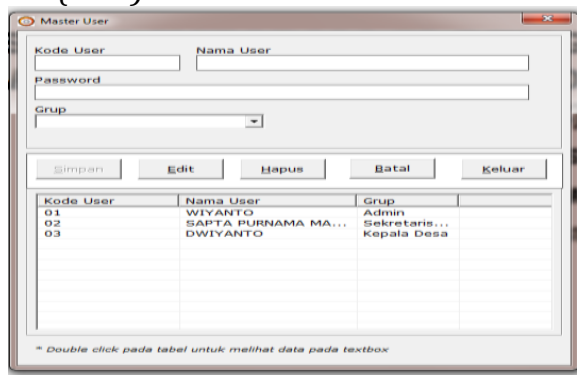

Gambar 13. Form Master Data

\section{Kesimpulan dan saran}

\section{A. Kesimpulan}

Berdasarkan penelitian dan sistem yang sudah dikembangkan oleh penulis dapat disimpulkan bahwa sistem informasi pengelolan anggaran pendapatan dan belanja desa di kelurahan getas dapat membantu dalam penyusunan anggaran pendapatan dan belanja desa sehingga waktu yang dibutuhkan cukup cepat, serta dengan adanya sistem informasi pengelolaan anggaran pendapatan dan belanja desa diharapkan dalam penyusunan anggaran tidak perlu membuat form laporan karena form yang dibutuhkan telah tersedia, dan dengan adanya hak akses user akan meminimalisir tindak kejahatan dari oknum yang tidak bertanggung jawab.

\section{B. Saran}

Penulis menyadari masih banyak kekurangan sistem ini, terutama kebutuhan form yang nantinya pasti akan lebih banyak dibandingkan yang ada pada saat ini, dan perlu dikembangkan sistem online atau berbasis website bagi peneliti selanjutnya.

\section{Daftar Pustaka:}

[1] Agusli, R. (2017). Sistem Pakar Identifikasi Tipe Kepribadian Karyawan Menggunakan Metode Certainty Factor. Vol 7 No 1 ISSN.

[2] Borg, G. (1983). Educational Research: AnIntoducation. New York: Longman.

[3] Davis Budi Purnama, H. W. (2015). Sistem Informasi Akuntansi Pengelolaan Alokasi Dana Desa Untuk Menilai Akuntabilitas Kinerja Desa. Vol. 1 No. 1 Universitas 17 Agustus 1945 Surabaya.

[4] Juaini, M. A. (2018). Sistem Informasi Pengolahan Data Inventaris Dan Pengadaan Barang Pada Kantor Desa Lenting Berbasis 
Web. Jurnal Manajemen Informatika \& Sistem Informasi.

[5] Muhammad Ismail, A. K. (2016). Sistem Akuntansi Pengeloaan Dana Desa. Vol. XIX No.2 ISSN 1979-6471. Universitas Sebelas Maret.
[6] Parwati. (2014). Sistem Komputerisasi Pengolahan Rapot secara Multiuser. ISSN 2338-4018. 